\title{
Research on the Strategic Transformation of China's Retail Enterprises Based on the Operating Data of Suning Group in Recent Ten Years*
}

\author{
Jun Li \\ School of Management \\ Hubei University of Chinese Medicine \\ Wuhan, China
}

\author{
Haiyun Wang \\ Law School \\ Central China Normal University \\ Wuhan, China
}

\begin{abstract}
The rapid development of China's Internet retail enterprises has made a huge impact on the traditional retail industry. The change of the industry model has made the growth rate of the traditional retail industry decline. In this case, traditional retail enterprises must be transformed to cope with the impact. In recent years, support for electricity providers to replace the entity retail industry has been weakening. Tmall, Jingdong, Amazon and other enterprises are developing towards the "Internet plus entity retail" mode. As a traditional retailer, Suning began its strategic transformation in 2009, and summarized a series of development programs such as cloud business model and achieved success. This paper combines the ten-year operation data of Suning E-commerce, uses the literature analysis method and case analysis method to analyze and summarize the transformation of Suning. It mainly includes four parts: one is the analysis of the current situation of retail business in China, the other is the understanding of the general situation of Suning E-commerce Group, the third is the analysis of the nearly ten-year operation data of Suning, and the fourth is the reference significance of the strategic transformation of Suning. It is hoped that through the analysis of the general situation of Suning's transformation, it can provide reference and suggestions for the transformation of Chinese traditional retail industry.
\end{abstract}

Keywords-Suning; E-commerce; strategic transformation

\section{INTRODUCTION}

Over the past decade, China's Internet retail industry has shown an explosive growth. With its advantages of convenience, speed and variety of shopping, it has brought a huge impact on traditional retail enterprises. Traditional enterprises must adapt to new changes and innovate business models in order to seek new opportunities for development.

Suning began to carry out strategic transformation in 2009. With its huge leading advantage in the real industry, it combines the real retail business with the Internet, and has found a way of Suning mode. As the leader of the transformation of the traditional retail industry, it has provided important experience for the transformation of

* General Topic of Educational Science Planning in Hubei Province, No. 2018GB025 retail enterprises in China.

This paper analyses how to carry out the strategic transformation and the problems in the transformation of Suning Group. Based on the ten-year operation data of Suning Group, this paper uses the literature analysis method and case analysis method to conduct in-depth discussion, hoping to provide some reference for the strategic transformation of traditional retail enterprises in China.

\section{ANALYSIS OF RETAIL BUSINESS IN CHINA}

\section{A. Development Status of Traditional Retailing Industry}

According to the annual operation statistics of Baixie in mid-2017 (see "Table I"), the total sales volume of department stores in 2017 was 71585.514 billion Yuan, at an increase of $9.10 \%$ over 2016; the total profit was 6.121 billion Yuan, at a decrease of $10.15 \%$ over 2016; the main business profit was 19.195 billion Yuan, at an increase of $232 \%$ over 2016 . At the end of the year, the total assets amount to 147.036 billion Yuan, at an increase of $0.32 \%$ over the previous year. [1] 
TABLE I. OPERATING CONDITIONS OF CCAGM With 85 MEMBERS COMPANIES

\begin{tabular}{|l|l|l|l|l|}
\hline & \multicolumn{1}{|c|}{$\mathbf{2 0 1 7}$} & \multicolumn{1}{|c|}{$\mathbf{2 0 1 6}$} & \multicolumn{1}{|c|}{ Annual change } & \multicolumn{1}{|c|}{ Tolerance (\%) } \\
\hline Date of total sales (ten thousand Yuan) & 71551361.21 & 65584989.03 & 5966372.18 & 9.1 \\
\hline Main business profit (ten thousand Yuan) & 1919480.7 & 1875880.59 & 43600.11 & 2.32 \\
\hline Total fees (ten thousand Yuan) & 2784935.5 & 2655362.03 & 129573.47 & 4.88 \\
\hline Operating expense (ten thousand Yuan) & 1904985.32 & 1661527.24 & 2434458.08 & 14.65 \\
\hline Total profit(ten thousand Yuan) & 612063.73 & 681216.91 & -69153.18 & -10.15 \\
\hline Ratio of sales (\%) & 2.2 & 2.52 & -0.32 & -12.81 \\
\hline $\begin{array}{l}\text { Total assets at the end of the year(ten } \\
\text { thousand Yuan) }\end{array}$ & 14703588.9 & 14657219.23 & 46369.67 & 0.32 \\
\hline $\begin{array}{l}\text { Net assets at the end of the year(ten } \\
\text { thousand Yuan) }\end{array}$ & 5491039.99 & 5460925.35 & 30114.64 & 0.55 \\
\hline Average number of employees & 175982 & 179444 & -3462 & -1.93 \\
\hline Operating acreage $\left(\mathrm{m}^{2}\right)$ & 20465055.03 & 19581767.45 & 883287.58 & 4.51 \\
\hline
\end{tabular}

It can be seen that the sales of traditional retail industry is gradually increased. At the same time, under the guidance of the "Internet + initiative" policy environment, the traditional retail market has generally upgraded its formats, and has gradually improved the retail efficiency by using digitalization and Internet means. Among the enterprises surveyed, $86.3 \%$ of them had already carried out the business of $\mathrm{O} 2 \mathrm{O}$. Among them, 54.8\% of enterprises used Ecommerce mode. Enterprises with self-built platforms accounted for $73.3 \%$. 37.0\% of the department stores surveyed had self-built mobile phone APP, realizing a 10 percentage points higher than that in 2016.

\section{B. The Development of Retail E-commerce in China}

China's E-commerce development has been in a mature period, the emergence and development of E-commerce once broke the sales model of retailers, and promoted the transformation and upgrading of China's retail industry. But the welfare of the Internet population has gradually reached the peak. According to the data of the National Bureau of Statistics, the growth rate of online retail sales in China had been declining from 2014 to 2016, and the growth rate in 2016 was only about half of that in 2014 [2]. At the same time, according to the data released by China Electronic Commerce Research Center in 2018, the cost of Tmall and Jingdong Mall passengers continues to rise, and the cost of online passengers per capita has exceeded 200 Yuan. In this case, Internet enterprises are also facing new development difficultioc

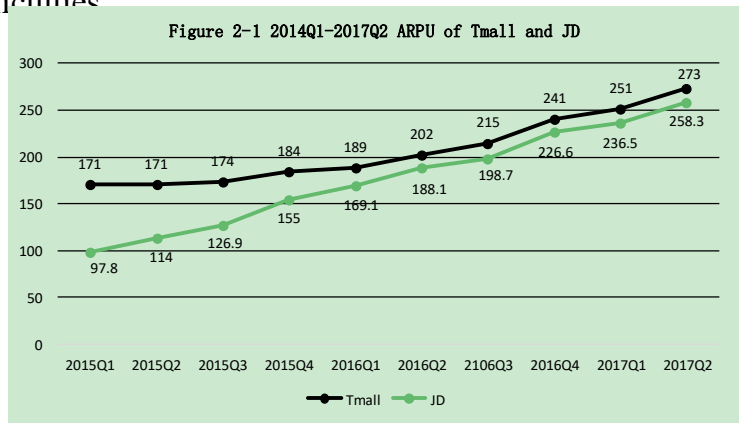

Fig. 1. 2014Q1-2017Q2 ARPU and JD. a. Source: A report on the development of retail trade in China's department stores 2017-2018

In October 2016, the concept of "new retail" was first proposed by Ma Yun. "New Retail", that is, the close combination of online and offline and logistics, its core is to make full use of the data of consumer-centered membership, payment, inventory, service and so on [3]. Based on the concept of "new retail", Internet enterprises gradually penetrate into the offline market, showing acquisition, stocktaking, cooperation with traditional retailers or establishing their own brands, such as Alibaba Group's stock-taking in Suning, Jingdong Mall's cooperation with Wal-Mart supermarket, Alibaba Group's creation of its own brand Hema store, etc.

\section{The GENERAL SituAtion OF SUNING}

\section{A. Introduction of Suning}

Suning Group was founded in Nanjing Ninghai Road in 1990, and has become a powerful retail enterprise after experiencing the development of chain operation mode and cloud merchant mode. Suning now has more than 600 stores and outlets in more than 4000 cities around the world. Through the development of Suning's E-commerce platform and third-party platform for online retail operation, Suning has successfully occupied the third place in China's B2C market, after Alibaba Group and Jingdong Mall. In 2017, Suning ranked 485 on the Fortune 500 list for the first time.

\section{B. Suning's Three Stages of Development Model}

1) First stage: Suning air conditioner (1990-1998): Suning was founded in 1990. Its predecessor was an air conditioning franchise. In 1991, Suning set up a after-sales service center to provide door-to-door installation and free delivery services not provided by state-owned shopping malls. At the same time, relying on the business model of "off-season ordering, off-season payment", we can get the preferential price supplied by manufacturers and reduce the sales price. In 1993, Suning, which has accumulated a good reputation and a certain amount of funds, became famous in the air conditioning competition. Subsequently, Suning Electrical Appliances continued to expand and gradually established a nationwide wholesale network. 
2) Phase II: Suning Electrical Appliances (1999-2009): In 1999, Suning opened Xinjiekou flagship store in Xinjiekou, Nanjing, marking the transformation of Suning's chain operation mode from exclusive air conditioning to integrated electrical appliances. At this stage, Suning has established a full coverage of physical chain stores from first-line to fourth-line cities, leading the 3C business. At the same time, Suning builds an efficient management platform by means of information management from the matrix management structure based on "specialization division of labor, standardization of operation" and the first generation electrical chain professional ERP information system to SAP/ERP system [4]. In 2005, Suning launched the "5315 Service Project" in the field of logistics and service, through which it plans to establish a nationwide integrated logistics distribution system and after-sales service system. In 2004, Suning was listed on the Shenzhen Stock Exchange and became the first listed company in China's retail industry.

3) Phase III: Suning Cloud (2010- ): In February 2010, Suning.com officially launched. In 2012, it gradually

Generally speaking, Suning's sales and profits have maintained a positive growth trend. Among them, sales have increased $276.63 \%$ in ten years and profits have increased $93.24 \%$ [8]. It can be seen that Suning has been in good involved department stores, finance and other fields. At the beginning of 2013, Suning put forward a new model of "store merchants + E-commerce + service retailers", emphasizing that store merchants should be the main force to develop local operation and services. In 2015, Suning put forward the strategy of "one body, two wings, three clouds and four ends", relying on supply chain, developing online and offline dual platforms, creating logistics cloud, data cloud and financial cloud, and integrating TV, computer, mobile and store.

According to the data of the annual report of Suning in 2017 , by the end of 2017, Suning had 3799 stores, 345 million registered users of Suning Group, 6.86 million square meters of warehousing and related supporting area of Suning Logistics and Tiantian Express, 20,871 express outlets, the next day and half-day service covering 319 cities in China.

\section{ANALYSIS OF THE STRATEGIC TRANSITIONS OF SUNING GROUP (2008-2017)}

\section{A. Business Data Summary from 2008 to 2017}

condition during the ten-year transformation and the transformation has been recognized by the market (see "Table II").

TABLE II. SUNING's OPERATING DATA

\begin{tabular}{|c|c|c|c|c|c|c|}
\hline years & $\begin{array}{c}\text { Sales (thousands } \\
\text { of Yuan) }\end{array}$ & $\begin{array}{l}\text { Sales growth } \\
\text { rate }(\%)\end{array}$ & $\begin{array}{c}\text { Profit } \\
\text { (thousands of } \\
\text { Yuan) }\end{array}$ & $\begin{array}{l}\text { Net profit } \\
\text { margin (\%) }\end{array}$ & store & $\begin{array}{l}\text { Store growth } \\
\text { rate }(\%)\end{array}$ \\
\hline 2008 & 49896709 & 24.27 & 2179913 & 4.37 & 812 & 21.50 \\
\hline 2009 & 58300149 & 16.84 & 2889956 & 4.96 & 941 & 15.89 \\
\hline 2010 & 75504739 & 29.51 & 4011820 & 5.31 & 1311 & 39.32 \\
\hline 2011 & 93888580 & 24.35 & 4820694 & 5.13 & 1684 & 28.45 \\
\hline 2012 & 98357161 & 4.76 & 2676119 & 2.72 & 1664 & -1.19 \\
\hline 2013 & 105292229 & 7.05 & 371770 & 0.35 & 1585 & -4.75 \\
\hline 2014 & 108925296 & 3.45 & 866915 & 0.80 & 1650 & 4.10 \\
\hline 2015 & 135547633 & 24.44 & 872504 & 0.64 & 1577 & -4.42 \\
\hline 2016 & 148585331 & 9.62 & 704414 & 0.47 & 1510 & -4.25 \\
\hline 2017 & 187927764 & 26.48 & 4212516 & 2.24 & 3799 & 151.59 \\
\hline
\end{tabular}

Seen from different years, the growth rate of sales and net profit margin of Suning can not guarantee a stable situation, and fluctuates greatly. From 2008 to 2011, the sales growth rate maintained a double-digit growth. During this period, Suning's main actions were to develop a four-inone scheme of rent, construction, purchase and merger, to promote three-dimensional chain development, to establish and put into use Nanjing Yuhua Logistics Base, to expand, transform and enter the international market through the acquisition of Japanese LAOX electrical appliances and Hong Kong laser, and to go online. Suning Group Platform. From 2012 to 2014, the domestic macroeconomic growth slowed down, the retail industry was facing a dilemma of sustained decline in growth, and the growth rate of Suning's turnover also dropped significantly. In 2013, Suning fully transformed the "cloud merchant" model and entered the deepening stage of enterprise transformation. Suning increased its investment in marketing, logistics platform, personnel reserve and other fields. The investment of advanced reserve affected the net profit margin. In 2014, Suning earned 1.974 billion Yuan from REITs-like capital operations, which helped Suning turn losses into profits at one stroke and slowly recover its operating profit margin. In 2017 , with the accumulation of retail, logistics and finance 
for many years, Suning has accelerated its scale. The overall layout of Suning's smart retail has achieved remarkable results.

\section{B. Channel Strategy}

Retail channel is the key point for retailers to control. As the ultimate link in the field of circulation, retail channel ultimately serves consumers directly, which determines the survival of a retail enterprise. In the strategic transformation of Suning, the concept of cloud merchant is put forward as "store merchant + E-commerce + retail service". On the one hand, it integrates offline stores, on the other hand, it develops online platforms. Through the upgrade of Internet in physical stores and the development of mobile applications, the full channel layout of stores, computers, mobile terminals and TV terminals has been realized, the offline platform has been opened, and the information flow has been realized.

"Shopkeeper" refers to all off-line stores in Suning. Before 2010, Suning mainly set up flagship stores, central stores and community stores to operate household appliances-based businesses. After 2010, Suning gradually expanded the types of stores and adjusted its business format (see"Table III"). At present, Suning has formed "one big, two small, multi-specialized" business layout.

TABLE III. SUNING'S STORE

\begin{tabular}{|l|l|}
\hline years & \multicolumn{1}{|c|}{ Type of store } \\
\hline 2008 & flagship stores; central stores; community stores \\
\hline 2009 & flagship stores; central stores; community stores \\
\hline 2010 & flagship stores; central stores; community stores ;boutique; town store \\
\hline 2011 & flagship stores; central stores; community stores; boutique; town store; Tesco store \\
\hline 2012 & flagship stores; central stores; community stores; boutique; town store; Tesco store \\
\hline 2013 & flagship stores; central stores; community stores; town store; Tesco store; red kids store \\
\hline 2014 & flagship stores; central stores; community stores; town store; Tesco store; red kids store; market \\
\hline 2015 & flagship stores; central stores; community stores; town store; Tesco store; red kids store; market \\
\hline 2016 & flagship stores; central stores; community stores; town store; red kids store; market; corner store business \\
\hline 2017 & Home appliance and 3C store; mother to child store; market; corner store business; Suning direct-sale store \\
\hline
\end{tabular}

Source: Suning annual report 2008-2017

"E-commerce" refers to Suning.com, Suning app and Suning's Tmall store. In 2010, Suning officially established Suning.com, and developed "combination of reality and reality" strategy of the electric business. With the popularity of mobile, Suning launch the app. By increasing the investment in the platform, opening payment platform, providing consumer finance loans and a series of actions, Suning formed a set of system of electrical quotient. In August 2015, Suning opened the Tmall store, which used the customers of the Tmall and expanded the consumer group.

While developing the two channels, Suning also fused the two channels. In June 2013, Suning announced the strategy of same price and same category, this is a key step in multi-channel integration, but also marks the full operation of Suning's O2O mode.

Then Suning continuously integrated channels through information fusion, logistics and distribution, and increasing after-sales service outlets, so that consumers can experience the complete shopping service.

\section{Financing Strategy - Class REITs}

Suning listed in 2004, equity financing is the normal model of Suning financing, but with the transformation of Suning, it need a lot of money. In 2014, Suning cooperate with CITIC Stone Fund, through capital operation of category REITs, Suning received 4.442 billion Yuan.

REITs is the organization of a company or business trust that brings together investors ' funds to acquire and hold real estate (generally gainful property) or to finance for real estate and enjoy tax incentives [5]. Most of the products released in the Chinese market are partly in line with the REITs operation process, so it is called class REITs operation. In 2014, Suning set up the house ownership and land use right of its 11 stores, respectively. The private equity fund was set up by CITIC Stone fund, which acquired $100 \%$ of Suning's project company in the name of the private fund. Suning continues to use its stores through after-sales lease and leases them at a stable rent, which will not affect the normal operation of the enterprise while activating funds. The move brought Suning $\$ 1.974$ billion in after-tax net income and helped turn Suning into a profit. In 2015, Suning operated 14 of its own stores, bringing a net profit after tax of 1.38 billion Yuan. In 2016, Suning operated six of its own logistics and warehousing centers, bringing a net profit of 510 million after tax.

Through the operation of REITs, Suning has revitalized its own property and increased its financing. At the same time, it has invested the funds obtained into operation, providing abundant financial support for Suning's strategic transformation.

\section{Logistics Strategy}

Logistics is an important part of the supply chain. Suning established the first logistics distribution center and 10 after-sales service outlets in Nanjing in as early as 1997. In 2012, Suning Logistics, independent from Suning, became a third-party logistics company. In 2016, Suning acquired 
Tiantian Express. By the end of 2017, Suning Logistics and Tiantian Express have $6860000 \mathrm{~m} 2$ logistics area and other supporting equipment. The logistics network radiates 352 prefecture level cities and 2906 districts and counties in the country. Suning is ahead of the vast majority of enterprises in logistics competition. On the basis of a strong logistics system, Suning further promotes customer service, shortens the delivery time of goods, and provides goods in person inspection and delivery service.

In the aspect of logistics, Suing has formed a full value industrial chain combining logistics assets operation with the whole process of warehousing, transportation and distribution with the integration of location, development and construction. In 2017, Suning logistics socialized operating income increased by $135.76 \%$ over the same period last year.

\section{REFERENCE TO SUNING CASE FOR STRATEGIC TRANSFORMATION OF CHINA'S RETAIL INDUSTRY}

\section{A. Vigorously Developing E-commerce}

The number of consumers in real business contacts is limited, the cost of expand the market is high, and the mobile terminal is popularized in a large scale, so it is imperative to carry out the "Internet + initiative" strategic transformation.

Suning formally launched suning.com in 2010, and set up an E-commerce operation headquarters on the organizational structure, and gradually transformed from household electrical appliance enterprises to retail department stores. Since 2012, Suning's sales begin to rank in the third place of B2C network platform. In 2015, Suing worked with Ali to set up a suning.com Tmall flagship store in Tmall. With the influence of Tmall and the reputation of Suning, Suning got a good business income. In 2017, Suning double eleven total merchandise trade increased by $163 \%$, and online orders increased by $210 \%$. Through 7 years of accumulation, Suning achieved explosive growth.

In the process of transformation, the traditional retail enterprises can choose to build the platform or enter the third party platform. The self-built platform has high risk, but it is easier to achieve explosive growth. The third party platform will invest small risks, but it will be affected by the development of the platform. In any case, it is necessary for retail companies to develop online platform.

\section{B. Getting Online and Offline Deeply Integrated}

The biggest difference between traditional retail companies and internet retailers is that traditional retail companies have physical stores. And from offline to online is bound to face a series of conflicts. The transformation of retail enterprises is not simply to set up online platforms, but to integrate resources of offline and online to bring maximum benefits to enterprises.

Suning's strategic transformation also faces conflicts, including product, price, channel, customer service and distribution channel conflict [6]. In 2013, Suning began to integrate offline and online industry. On June 2013, Suning announced that all were sold on the same price. In the establishment of stores and the positioning of the electric business, Suning believes that offline and online must be both strong in developing the online platform vigorously and transforming the store experience constantly. Finally, the pattern of "one big, two small, multi specialized" was created. At the same time, Suning understands consumer needs through information fusion, and provides more precise services to users with different consumption scenarios. In the distribution, Suning logistics provides logistics services both online and offline, Users can also get the goods by self-lift. In terms of services, Suning increased investment in aftersales service outlets, providing consultation and repair services for both online and offline businesses. Through online and offline integration, consumers can have an integrated shopping experience, which reduces consumer concerns and improves consumer satisfaction.

\section{Raising the Level of Capital Operation}

Enterprise transformation generally needs to face a lot of risks, a large amount of capital investment. In addition to the revenue generated by sales, the transformation of retail enterprises also needs to consider how capital operation can get capital in the case of minimizing risks.

Suning invested heavily in the transformation process, and once appeared negative profit in the process of transformation. In order to obtain more funds, Suning began to cooperate with CITIC in 2014, for class REITs operation. Without affecting the operation of the entity store, through the operation of real estate, after sale leaseback, the fixed assets will be converted into working capital. This movement brings billions of the funds to Suning.

Suning was listed in 2004. Equity financing channels have always existed. The traditional retail enterprises are not always listed companies. The transformation of some enterprises itself lacks the channel of equity financing. In the process of transforming investment, it is more important to pay more attention to capital operation so as to avoid the breakage of capital chain.

\section{Improving the Logistics System}

The logistics quality and time limitation have become an important part of the retailer's competition. In the process of transformation, the retail enterprises must adjust the storage and distribution services to make it more appropriate to the market demand.

In the course of its development, Suning independently developed the Suning logistics. By integrating the upstream and downstream of the supply chain and combining the information resources, Suning has established a perfect logistics network and is committed to creating a new era of intelligent logistics. The improvement of the logistics system provides the necessary conditions for shortening delivery time and covering more extensive areas, so that consumers can experience better distribution services and provide conditions for expanding the marketing scope of Suning products. 
Self-built logistics is a fairly large layout for enterprises. The huge investment in early stage is a big challenge for traditional retail enterprises. But according to the strategic layout experience of Alibaba, JD.com and Suning, self-built logistics is the trend of the future retail industry, and the enterprise is becoming increasingly fierce in the logistics competition, and the improvement of logistics system is an important aspect for enterprises.

\section{CONCLUSION}

From the overall data point of view, Suning's sales increased by $276.63 \%$ in ten years, and profits increased by 93.24\%, which means Suning's transformation was successful. Through this study, we can see that the reasons for Suning's success in transformation are as follows. Firstly, it develops online business and enters E-commerce. Through the online suning.com platform, Suning has opened the road of transformation. The launch of the platform makes Suning available to a broader customer group and more space for commodity display; secondly, it realizes the integration of line and line. Channel conflict is the dilemma of the transformation of traditional retail enterprises. Through the online and offline price, the transformation of the store, information fusion, the increase of the number of service outlets, and other measures to solve the problem of channel conflict step by step; thirdly, it makes use of capital operation to obtain sufficient funds. Through the operation of class REITs, Suning makes enterprises getting a lot of liquidity and put power into the later period; fourthly, it establishes a perfect logistics system and gains the dominant position of competition. The perfect logistics system has surpassed most retailers and formed the threshold of competition.

The problems encountered in the transformation of Suning are many of the problems that the retail enterprises must face, and the retail enterprises should respond as soon as possible in the process of transformation. The solution of the problem can also provide important reference for the transformation of the retail enterprises in China.

\section{REFERENCES}

[1] Ministry of Commerce of the People's Republic of China Department of Circulation Industry Development, China Commerce Association for General Mechandise, Fung Business Intelligence. China's Department Stores Report 2017-2018.

[2] Ministry of Commerce of the People's Republic of China. (2017) China's E-commerce Report 2016.

[3] China Distribution 30 Forum Secretariat, editorial department, Yingze Lin, Yu Ge, Wenbin Bao. From Ali and Bailian "marriage" to see "new retail". In: China Business and Market. (2017) 31(03):124128.

[4] Hua Lan. (2017) Research on the strategic transformation of Su Ning Yun business group in the era of "Internet +". Minzu University of China, 2017.

[5] Lingling Lu, Jian Zhou. REIT and REITs. In: Technoeconomics \& Management Research. (2007) (4):118-119.

[6] Peng Fan. Retail channel "cloud transformation". In: Economic \& Trade Update. 2017 (08):7-11. 